УДК 140.8

DOI 10.35423/2078-8142.2020.1.03

Н. В. Дев'ятко, кандидат філософських наук, дочент кафедри філософії КЗВО «Дніпровська академія неперервної освіти» ДОР м. Дніпро, Украӥна e-mail: Natalia_ptah@ukr.net ORCID: https://orcid.org/0000-0003-0162-1194

\title{
МІФОЛОГІЧНІ СТРУКТУРИ МЕДІЙНИХ ТЕКСТІВ: ОСНОВНИЙ ЗМІСТ ТА СПЕЦИФІКА ВПЛИВУ
}

У статті досліджуються зміст та специфіка впливу медійних текстів на світогляд людини, коли їхні структури актуалізуються за міфологічними принципами. Аналіз проблеми відбувається на основі порівняння спільних $i$ відмінних характеристик масової комунікації $i$ комунікації, яка набуває міфологічних ознак у контексті мас-медійного дискурсу. Відзначається, що у сучасному світі засоби масової інформації виконують основну функцію каналізації почуттів, вражень та очікувань масової свідомості та мають значний вплив на формування сочіальних груп та суспільства. На свосму структурному рівні спілкування засоби масової інформації всіх типів використовують міфологічні принципи передавання інформації, а також кодування та розшифрування значень, які мають емочійно важливе навантаження. Важливо зрозуміти принципи того, в який спосіб виражені та приховані значення в текстах ЗМІ вкладаються у світогляд, спрямовують людські дії та коригують людське сприйняття як політичних, так $i$ культурних явищ. У статті досліджено зміст та вплив фокусу, який медіатексти набувають, коли їх структури актуалізуються відповідно до міфологічних принципів.Описуються базові характеристики медійного тексту як комунікативного феномена впливу на світогляд особистості і великі аудиторї. Окрема увага приділена дослідженню взаємовпливу головних структурних особливостей національного, культури, політики і медіа.

(C) Дев’ятко Н. В., 2020 
Ключові слова: міф, світогляд, комунікація, мас-медіа, національне.

Маючи значний вплив на формування соціальних груп $\mathrm{i}$ суспільство в цілому, мас-медіа нині виконують головну функцію каналізації почуттів, вражень та очікувань масової свідомості. Завдяки цьому дискурс мас-медіа стає не лише потужним чинником впливу на світоглядні установки людей, а й основним інструментом для створення і підтримки повноцінної діяльності світоглядно-комунікативних систем, що саме по собі $\epsilon$ комунікативним феноменом сучасного світу. Постійна взаємодія із суспільством істотно впливає на структури та світоглядний зміст самих мас-медіа й інформаційні тексти, які вони створюють. Зважаючи на структурно-світоглядні особливості масової свідомості, можна припустити наявність використання на структурному рівні комунікації у мас-медіа міфологічних принципів передавання інформації та кодування і декодування смислів, які мають емоційно важливе навантаження. У сучасному світі саме мас-медіа виконують роль каналу масової комунікації для парадигмальних світоглядних ідей i смислів та стають основним джерелом смислового й емоційного наповнення соціальних мереж. Це відбувається не лише шляхом прямого перепосту, а й через емоційне переосмислення та підкріплення власними аналітичними і творчими розвідками дописувачів, що також є цікавим феноменом сучасності.

Специфічність і структурні побудови медійних текстів у словесному, аудіо, візуальному, символьному, відео-форматах постійно досліджуються у вітчизняній та зарубіжній науці. Зокрема, у працях Н. Лумана [14], Г. Маклюена [15], а також Н. Більовської [2], І. Срофеєвої [10], Л. Павлюк [16] та ін. Відкриваючи різні грані проблеми, дослідження не дають повної і чіткої відповіді, на основі чого базується потужний вплив сучасних масмедіа на свідомість і підсвідомість людини та яким чином висловлені і приховані смисли вбудовуються у світоглядну картину світу людини, скеровують іiі вчинки i корегують сприйняття як політичних, так i культурних явищ. У цьому контексті пропонуємо подивитися на проблему висловлення основ- 
ного змісту та специфіку впливу медійних текстів, які продукують мас-медіа, крізь призму досліджень міфологічного світогляду та міфологізації масової свідомості, яка у кризові епохи досягає максимуму. Найбільше, звісно, нас цікавить реалізація цих принципів у вітчизняному інформаційно-культурному просторі.

Метою статті є дослідити базові міфологічні структури медійних текстів у контексті їхнього смислового наповнення та специфіки впливу на світогляд особистості і масову аудиторію.

Завдання полягають у такому:

- аналіз спільного й відмінного у масовій і міфологічній комунікації у мас-медійному дискурсі;

- опис базових характеристик медійного тексту як комунікативного феномена впливу;

- дослідження взаємовпливу головних структурних особливостей національного, культури, політики і медіа.

Для того, щоб комунікація здійснилася, має утворитися світоглядно-комунікативний простір, через який i відбувається кодування та декодування інформації. Зокрема, про такий простір можна говорити як про «національний інформаційний простір» (О. Гриценко і В. Шкляр [5, с. 193-194]), соціально-інформаційне комунікативне поле політики (О. Чадюк [20, с. 7]), яке активно впливає на зміст самої комунікації. Важливість комунікації для людини на національному i світоглядному рівнях підтверджує В. Буряк: «Людська свідомість інформаційна за своєю суттю. Кожен почуттєвий образ предмета або відчуття, уява становить частину свідомості, а, отже, вони володіють певним значенням та смислом» [4, с.27]. Тобто можуть бути закодовані чи стати втіленням комунікативних кодів, бути основою міфологічних образів та передумовою актуалізації глибинних архетипів, оскільки сама інформація має здатність формувати навколо себе «комунікативне свідомісне поле» [4, с. 3]. Ця властивість інформації поширюється на процес комунікації і засоби масової інформації в цілому, що надає право говорити про комунікацію у мас-медіа як міфологічну за способом, але не завжди міфологічну за суттю. Н. Луман, наприклад, пише про властивість мас-медіа до створення трансцендентальної ілюзії (за кантівською термінологією) [14, с. 13]. А також на тих, хто вступає у комунікацію. Наприклад, 


\section{Н. Більовська розглядає учасників комунікації «адресанта» i} «адресата» у сучасних мас-медіа як «архетипну пару» [5, с. 212], що також $є$ міфологічною категорією.

Взаємовплив комунікативних i міфологічних світоглядних структур має глибоке архетипне коріння. Д. Усов розглядає «міфічне слово» як повідомлення із символьно-знаковою природою, пов'язуючи його 3 комунікацією і масовою свідомістю [19, с. 9]. Комунікація, так само, як і світоглядний міф, лежить в основі будьякого руху, що має духовне чи ідейне наповнення. Так, К. Дойч стверджує, що «ні спільнота, ні культура не існують поза суспільством. Але не може бути суспільства... без мінімальної передачі інформації, без комунікації» [8, с. 555]. Культура ж має міфологічну природу, а завдяки можливості залучення до поля свого впливу речей, дій, ідей, особистостей світоглядний міф формує спільноти, які гуртуються за подібністю світоглядних уявлень, тобто, для поширення становлення і саморозвитку, такий міф, який діє через інформаційно-культурний простір, потребує комунікативних процесів.

На думку К. Дойч, комунікація є необхідною і для існування народу: «Велику групу осіб, об’єднаних наявністю саме таких взаємодоповнюючих звичок та засобів комунікації, якраз і можна назвати народом» [8, с. 556]; а саме через світоглядний міф у національному горизонті проявляються світові та національні архетипи, що теж підкреслює взаємозалежність комунікації і міфу. В. Сленський визначає комунікативну функцію національного міфу поряд 3 іншими головними функціями міфу (інтегративною та когнітивною) [9, с. 189]; а К. Ясперс описує комунікацію в межах національної культури як тісний духовний зв'язок між людьми на основі «субстанційних життєвих смислів» [Цит. за: 17, с. 17].

I. Дзялошинський вважає, що «зіставлення характеристик міфу і масової комунікації виявляють не лише їхню подібність, ізоморфізм, а й здатність до взаємопосилення» [6, с. 36], що пояснюється життєвою необхідністю світоглядного міфу до комунікації, завдяки чому відбувається рух міфічної енергії. Л. Зубрицька розвиває ці ідеї: в обох системах відбувається «злиття загального, особливого та одиничного у діалектичну цілісність»; міф і масова комунікація «сприяють виникненню феномена глобальної 34

H.Skovoroda Institute of Philosophy of the NAS of Ukraine 
ідентичності, причетності до всього, що відбувається у світі»; міфологічний час й специфіка подання інформації у мас-медіа «поєднують у єдиний сплав минуле, сучасність i майбутнє» [11, с. 10]. Як засвідчують події останнього десятиліття, люди, об'єднані на основі природного світоглядного міфу, відзначаються чіткою національною самоідентифікацією, небайдужістю до всього, що їх оточує, відповідальністю за свої дії й активністю в усіх сферах життя. Подібний образ суспільного ідеалу може як підсилюватися i пропагуватися через мас-медіа, так i навпаки повсюдно позбавлятися важливості, що впливає насамперед на реалізацію права створення і легітимізації світоглядних кодів окремих груп людей. Дуже часто останнє реалізується через політичні контексти.

Н. Луман, описуючи комунікативні структури мас-медіа, виокремлює міфологічну функцію цієї системи до розпізнання і компенсації суперечностей, завдяки чому у системі «створюється реальність» [14, с. 153]. Завдяки цим особливостям міфологеми і світоглядні коди найчіткіше фіксуються у текстах мас-медіа, які відображають стан масової свідомості та базові світоглядні установки суспільства відповідно до історичного моменту. Г. Почепцов зазначає, що «зміни у комунікації (зокрема, у масмедіа) призводять до зміни моделі світу, що у свою чергу призводить до змін у поведінці» [Цит. за: 4,c. 35]. Цим підтверджується пов'язаність мас-медіа і світоглядного міфу, бо саме міф постає каталізатором глобальних світоглядних змін, завдяки йому на несвідомому рівні закладаються поведінкові матриці.

Внутрішній вміст світоглядного міфу відзначає і В. Бурлачук, який звертає увагу не лише на «семантичну структуру міфу, що являє собою особливу форму комунікативного зв'язку» [3, с. 120], а й на те, що для такої структури «характерним $є$ те, що одержувач повідомлення наділений особливим соціальним статусом» [3, с. 120]. Тобто, через причетність до сакрального (або псевдосакрального) людина, яка знаходиться у міфологічному просторі, набуває статусу виразника або носія світоглядного міфу, отримує визнання легітимності своїх дій та істинності думок. А. Темченко також аналізує структури міфу і доходить висновку, що 
«міф має декілька рівнів кодування i прочитання інформації, включаючи чуттєвий та інтуїтивний. Саме таке розуміння дає змогу «читати» міф не лише як текст (у вузькому розумінні цього терміна), тобто, послідовно, а й паралельно сприймати закладену в ньому інформацію (текст сприймається як символ, як неподільне ціле)» [18, с. 49], що не лише доводить особистісну цілісну природу світоглядного міфу, а й засвідчує важливість його вмісту, а не форми.

Завдяки тому, що мас-медіа оперують як словом, так i символами, а кодуванням інформації відбувається, зокрема, як образне, невербальна інформація світоглядного характеру може втілюватися у текстах у різноманітний спосіб, та найчастіше вербально.

Першою чергою це виявляється за способом. Переймання масмедіа формальної структури світоглядного міфу, виключаючи його внутрішню суть і замінюючи іiі власною інформацією, часто-густо ідеологічного характеру, $\epsilon$ цілком можливим. Н. Амельченко пояснює цю можливість, як і можливість використання міфу в політиці, тим, що у сучасному суспільстві «знак прийшов на зміну смислу» [1, с. 51]; докладно описує цей процес М. Кошелюк, розглядаючи технологічний міф як ідеальний «контейнер для передавання інформації» [13, с. 101]. Під впливом ерзацпостмодерну відбулася формальна підміна сутності, цей процес торкнувся всіх духовно-розумових проявів людського життя, як-то релігія, наука, мистецтво та політика, не залишився поза цим процесом і мас-медійний дискурс.

Уявлення про те, що $є$ текстом, а особливо, що $є$ медійним текстом, не є усталеними. I хоча думка про текст як про «мовний твір» $\epsilon$ поширеною, але маємо розглядати текст як знаковосимвольну систему, бо текст може реалізуватися не лише у слові, а й у знаку, образі чи символі, що можуть мати будь-яке втілення. Таким чином, текст може фіксувати несвідомі психологічні процеси й уявлення, а також окреслювати комунікативні процеси і головні характеристики активних у несвідомому символів i смислів, а особливо образів, що мають міфологічну основу й базуються на актуалізованих глибинних архетипах. Можливо навіть порівняти текстову фіксацію комунікативного процесу 3 мовним кореневим 36

H.Skovoroda Institute of Philosophy of the NAS of Ukraine 
кодуванням природного міфу та національних світоглядних уявлень, бо за принципами кодування інформації вони подібні.

Визначення медійного тексту, зокрема, дає Т. Добросклонська, яка вважає, що у мас-медіа «концепція медіатексту виходить за межі знакової системи вербального рівня, являючи собою послідовність знаків різних семіотичних систем мовних, географічних, звукових, візуальних, специфіка поєднання яких зумовлена конкретним каналом масової інформації» [7, с. 22]. Текст, маючи міфологічну природу та організацію, є одним із проявів світоглядно-комунікативної системи і фіксує комунікативні процеси, що дає можливість вивчення їх поза часом первинної комунікації, що відбувалась у момент кодування і передавання повідомлення. Для цього потрібно обов'язково чітко розуміти історичну специфіку і контекст, щоб не дивитися на тексти, створені у минулому, крізь викривлену призму сучасності, додаючи непотрібної постміфологізації закодованих раніше смислів. Хоча для посилення нового впливу у текстах мас-медіа і художніх творах буде використаний саме цей принцип, що значно підвищить енергетику кодового рівня, і це $\epsilon$ цілком природним явищем.

Інформаційно-культурний простір, в якому відбувається комунікація, має ментальну укоріненість через національний міф, що не суперечить базовим світовим міфологічним уявленням. Що, зокрема, відзначає А. Кармін, який вважає, що «менталітет $\epsilon$ проекцією ментального простору культури на психіку людей» [12, с. 213], а цей простір існує і функціонує завдяки комунікації. Знаходячись у такому просторі, всі «культурні форми», а також всі елементи (речі, дії, люди тощо), в яких може втілитися міфічна енергія, одночасно, на думку А. Карміна, «входять у нього, беруть участь у його створенні і разом із тим знаходяться під його впливом» [12, с. 121], що повністю відповідає особливостям міфологічної комунікації. Саме цей простір, як вважає дослідник, $\epsilon$ спільним полем, яке утворюється завдяки «ментальним полям, що оточують різні віртуальні форми, накладаються одне на одне» [12, с. 212]; те саме можна визначити i як властивість інформації, забарвленої ментально, тобто такої, що формує національний простір. Іншою особливістю $є$ те, що це поле 
«просякає весь простір, який займає певна національна культура або певний соціокультурний світ» [12, с. 212].

Водночас, пряма атака на національне і його виразників дуже швидко змінюе структури самого інформаційно-культурного простору i комунікацію у ньому, що автоматично спричиняє ентропію в усіх сферах життя. Ці актуалізовані процеси дуже добре спостерігаються сьогодні, й вони набувають катастрофічних ознак, що може змінити сам світоглядний вектор суспільства. За таких умов природний світоглядний міф набуває ознак технологічного i дуже швидко змінює світогляд масової аудиторії, що впливає на іiі судження i поведінку. Деструктивні дії проти природних національних структур активно використовуються у «гібридних війнах», насамперед у мас-медіа, саме шляхом зміни природного міфу на технологічний (у нашому випадку - імперський), як такий, що підмінить собою світоглядну кодову основу комунікації і змінить вектор майбутнього.

Таким чином, можна зробити висновок, що хоча сучасні медійні тексти зазнають постійних трансформацій, що зумовлено впливом глобалізації та повсюдним застосуванням ігрових принципів у комунікації, створенні і декодуванні інформаційних повідомлень, спостерігається доволі значна залежність сучасних медіа від міфологічного світогляду. Відбувається боротьба за світоглядну домінанту між світоглядними кодами конфліктних інформаційно-культурних просторів. Останнє найяскравіше нині відбувається на рівні національного. Зважаючи на це, важливими $є$ подальші дослідження комунікативних процесі і структур впливу мас-медіа на особистість та великі аудиторії.

\section{ЛITEPATУРA}

1. Амельченко Н. А. Міф та нація - переплетення філософського та політичного дискурсів. Філософська думка. 2003. № 6. С. 50-75.

2. Більовська Н. Категорії «автор-адресант» як знакові характеристики досягнення ефективності сучасних медіатекстів. Вісник Львівського університету. Серія Журналістика. 2018. № 43. С. 212-217.

3. Бурлачук В. Ф. Соціальні переживання та політичний міф. Політична думка. 2001. № 1-2. С. 110-121. 
4. Буряк В. Д. Журналістська творчість як система образної комунікації : навч. пос. Дніпропетровськ : РВВ ДНУ, 2003. 60 с.

5. Гриценко О. М., Шкляр В. І. Основи теорії міжнародної журналістики. К. : ВПЦ Київський університет, 2002. 304 с.

6. Дзялошинский И. М. Манипулятивные технологии в массмедиа. Вестник Московского университета. Серия Журналистика. 2005. № 1. C. 29-54.

7. Добросклонская Т. Г. Медиадискурс как объект лингвистики и межкультурной коммуникации. Вестник Московского университета. Серия Журналистика. 2006. № 2. С. 20-33.

8. Дойч К. Народи, нації та комунікація. Націоналізм : антологія. К. : Смолоскип, 2000. С. 546-566.

9. Єленський В. С. Релігія та процес націєтворення. Релігія $i$ нація в суспільному житті Украӥни й світу. К. : Наукова думка, 2006. С. 187206.

10. Ерофеева И. В. Психология медиатекста : учебник и практикум для вузов. М. : Издательство Юрайт, 2020. 206 с.

11. Зубрицька Л. Й. Міф як феномен сучасної політики : автореф. дис. ... канд. політ. наук : 23.00.01 / Київ. нац. ун-т ім. Т. Шевченка. Київ, 2005. 18 c.

12. Кармин А. С. Культурология. СПб. : Лань, 2001. 832 с.

13. Кошелюк М. Е. Технологии политических выборов. СПб. : Питер, 2004. 239 с.

14. Луман Н. Реальность массмедиа. М. : Праксис, 2005. 256 с.

15. Маклюэн Г. М. Понимание медиа: внешние расширения человека. М. : КАНОН-пресс, 2003. 464 с.

16. Павлюк Л. С. Текст і комунікаиія : основи дискурсного аналізу. Посібник. Львів: ПАІС, 2009. 76 с.

17. Скринник М. А. Буттєві смисли національної ідентичності в українському романтизмі : автореф. дис. ... д-ра філос. наук : 09.00.05 / Львівський нац. ун-т ім. І. Франка. Львів, 2008. 36 с.

18. Темченко А. Діалог як інформачійна модель (на матеріалах традиційної культури). Народна творчість та етнографія. 2005. № 1. C. 48-59.

19. Усов Д. В. Міфологізаиія свідомості в сучасному суспільстві : автореф. дис. ... канд. філос. наук : 09.00 .03 / Ін-т філософії ім. Г. С. Сковороди НАН України. Київ, 2002. 19 с.

20. Чадюк О. М. Метафора у сфері сучасної української політичної комунікації : автореф. дис. ... канд. філол. наук : 10.02.01 / Ін-т української мови НАН України. Київ, 2005. 20 с. 


\section{REFERENCES}

Amelchenko, N. A. (2003). Myth and nation - the interweaving of philosophical and political discourses. FIlosofska dumka (Philosophical thought), 6, 5075. [In Ukrainian].

Bilyovska, N. (2018). Categories of «author-addressee» as symbolic characteristics of achieving the effectiveness of modern media texts. Visnik Lvivskogo universitetu. Seriya Zhurnalistika (Bulletin of the University of Lviv. Journalism Series), 43, 212-217. [In Ukrainian].

Burlachuk, V. F. (2001). Social experiences and political myth. PolItichna dumka (Political thought), 1-2, 110-121. [In Ukrainian].

Buryak, V. D. (2003). Journalistic creativity as a system of imaginative communication: textbook. pos. Dnepropetrovsk : RVV DNU. [In Ukrainian].

Gritsenko, O. M. \& Shklyar, V. I. (2002). Fundamentals of the theory of international journalism. Kyiv : VOC Kiev University. [In Ukrainian].

Dzyaloshinsky, I. M. (2005). Manipulative Technologies in Mass Media. Vestnik Moskovskogo universiteta. Seriya Zhurnalistika (Bulletin of the Moscow University. Journalism series), 1, 29-54. [in Russian].

Dobrosklonskaya, T. G. (2006). Mediadiscourse as an object of linguistics and intercultural communication. Vestnik Moskovskogo universiteta. Seriya Zhurnalistika (Bulletin of the Moscow University. Journalism series), 2, 20-33. [In Russian].

Deutsche, K. (2000). Peoples, Nations and Communication. Nationalism : an anthology. Kyiv : Smoloskip, 546-566. [In Ukrainian].

Elensky, V. E. (2006). Religion and the process of national formation. Religion and nation in the social life of Ukraine and the world. Kyiv: Scientific Thought. 187-206. [In Ukrainian].

Erofeeva, I. V. (2020). Psychology of media text : a textbook and a workshop for high schools. Moscow : Yuryt Publishing House. [in Russian].

Zubritskaya, L. Y. (2005). Myth as a Phenomenon of Contemporary Politics (Author's Resume for a Degree Candidate of Political Sciences : 23.00.01). Kyiv National University. T. Shevchenko : Kyiv. [In Ukrainian].

Carmine, A. S. (2001). Cultural Studies. St. Petersburg : Lan. [In Russian] 
Koshelyuk, M. E. (2004). Technologies of political elections. St. Petersburg : Peter. [In Russian].

Luman, N. (2005). The reality of mass media. Moscow : Praxis. [In Russian].

McLuhan, G. M. (2003). Understanding the media: human external extensions. Moscow : CANON Press. [In Russian].

Pavlyuk, L. S. (2009). Text and communication : basics of discourse analysis. Manual. Lviv : PAIS. [In Ukrainian].

Skrynyk, M. A. (2008). Essential Meanings of National Identity in Ukrainian Romanticism. (Author's Resume for a Degree Doctor of Philosophy Sciences : 09.00.05). Lviv National University I. Franko : Lviv. [In Ukrainian].

Temchenko, A. (2005). Dialogue as an information model (based on traditional culture materials). Narodna tvorchIst ta etnografIya (Folk creativity and ethnography), 1, 48-59. [In Ukrainian].

Usov, D. V. (2002). The mythologization of consciousness in modern society. (Author's Resume for a Degree Candidate of Philosophical Sciences: 09.00.03). Institute of Philosophy GS Skovoroda of NAS of Ukraine : Kyiv. [In Ukrainian].

Chadyuk, O. M. (2005). Metaphor in Contemporary Ukrainian Political Communication. (Author's Resume for a Degree Candidate of Philological Sciences : 10.02.01). Institute of Ukrainian Language of NAS of Ukraine : Kyiv. [In Ukrainian].

\section{Nataliia Deviatko}

Candidate of Philosophical Sciences (Ph.D.), Associate Professor of the Department of Philosophy, The Dnipro Academy of Continuing Education; Dnipro, Ukraine; e-mail: Natalia_ptah@ukr.net; ORCID: https://orcid.org/ 0000-0003-0162-1194

Mythological structures of media texts: content summary and specificity of impact 


\begin{abstract}
In the modern world, the mass media perform the main function of channeling the feelings, impressions, and expectations of the mass consciousness and have a great influence on the formation of social groups and society. At their structural level of communication, media of all types use mythological principles of information transmission, as well as encoding and decoding of meanings that have an emotionally important load. It is important to understand the principles of how the expressed and hidden meanings in the media texts get embedded in the worldview, guide human actions, and adjust human perception of both political and cultural phenomena. The article examines the content and impact focus that media texts acquire when their structures are actualized according to mythological principles. The problem was analyzed by comparing the common and differing characteristics of mass communication and communication that acquires mythological features in the context of mass media discourse. The purpose of the article is to investigate the basic mythological structures of media texts from the perspective of their semantic content and specificity of influence on a mass audience. The article presents the analysis of common and different features in mass and mythological communication within mass media discourse and describes the basic characteristics of the display text as a communicative phenomenon of influence. The research also covers the interaction of the main structural features of national, culture, politics, and media aspects. The cultural environment actively influences the content of the information itself through the use of specific worldview codes in the process of encoding and decoding the messages. At the same time, the information itself and the form of its embodiment transform the part of the information field that is directly affected. The interplay of communicative and mythological outlook structures has deep archetypal roots, manifested primarily in how the information is infused with meaning as well as through the culture and creativity demonstrated by an individual.
\end{abstract}

Keywords: myth, worldview, communication, mass media, national. 